\title{
NITROGEN AND PHOSPHORUS REQUIRED FOR THE GROWTH OF PHYTOPLANKTON
}

\author{
By H. W. Harvey, Sc.D.
}

(Text-figs. I-2)

When offshore water, collected during the early part of the year, is enriched with nitrate, phosphate and an iron salt and is kept in a north window, a growth of phytoplankton develops. After a few days the plant community changes; typical planktonic diatoms give way to pennate forms while flagellates and other unicellular algae tend to become numerous. The colonial alga Phaeocystis continues growth and some species of centric diatoms, as Skeletonema, persist longer than others.

Similar changes in the community have been described by Allen \& Nelson (I9I0) who differentiate between the true plankton forms which flourish in the sea and the "aquarium forms which invariably take possession when present in mixed cultures, whilst the plankton forms are killed off. Why is it that, although species of the second class are always present in small numbers in plankton taken from the sea, they are there altogether outnumbered by the true plankton forms, whereas under conditions such as those of our experiments they invariably succeed in gaining the upper hand?"

This change appeared to start at about the time when, owing to photosynthesis by the increasing population of diatoms, the hydrogen-ion concentration fell and, collaterally, the partial pressure of dissolved carbon dioxide was reduced to a fraction of its normal value. By varying the quantity of excess base, some evidence was obtained which suggested that it was the reduced carbon dioxide pressure rather than increase in $p \mathrm{H}$ which caused the change in the community. Experiment showed that by keeping the partial pressure of carbon dioxide (and $p \mathrm{H}$ ) within reasonable bounds, considerable growths of typical planktonic communities would develop. These were free or almost free from flagellates and were similar in composition to the diatom communities occurring at that time in the sea but many hundred times more dense.

These growths were obtained by bubbling a rapid stream of washed and filtered air through the water, reducing the light during particularly bright weather if the $p \mathrm{H}$ rose unduly, and by limiting the supply of one or other nutrient salt. In this way it was possible to obtain natural planktonic populations of such density that they had utilized $200 \mathrm{mg}$./cu. m. of available phosphorus at room temperature in March. With longer and brighter days later in the year, such dense populations were not always obtained; the rate at which they utilized $\mathrm{CO}_{2}$ being, presumably, greater than the rate of supply 
from the air bubbles, and the change in community set in before so much nutrient was utilized. It was also found desirable to add a source of silica more readily available than from the glass walls of the flask; a solution of waterglass neutralized with hydrochloric acid proved satisfactory for this purpose.

Using this method of experiment it was possible to make various observations concerning the nutrient requirements of typical phytoplankton communities. Such communities include bacteria.

The number of bacteria occurring in nature in sea water rich in phytoplankton is greater than water poor in phytoplankton (Waksman et al., I933); there is reason to believe that some of these bacteria are epiphytic. It seems desirable therefore, in investigating the requirements of a phytoplankton community, to consider it as composed of both plant cells and bacteria, some of which may even play a part as symbionts. Indeed it is impossible to do otherwise in practice; it is not certain that marine diatoms have yet been obtained in culture free from bacteria.

On the other hand, it is necessary to consider how far these dense populations of phytoplankton grown from crude sea water resemble, not only in their plant species, but also in their bacterial content, communities occurring naturally in the sea.

When sea water is transferred to a glass vessel there is a rapid growth of bacteria. It has been shown that this growth is more rapid and greater the smaller the vessel, and depends upon the relation between the area of glasswater interface and the volume (Lloyd, 1937). ZoBell has suggested that organic matter dissolved in the water is adsorbed on the interface, where its localized concentration permits the bacteria to develop. Waksman et al. (1933) have followed the increase in numbers of both diatoms and bacteria in a culture, finding that the ratio of bacteria to diatoms increased from $3: \mathrm{I}$ to $20: \mathrm{I}$.

Although, in culture, the phytoplankton population becomes several, often many, hundred times more dense than in the sea, it seems probable that the supply of nutrient salts arising from bacterial decomposition of organic compounds proceeds at a rate, relative to the phytoplankton population, which is greater than would occur in nature.

\section{The Ratio of Nitrogen to Phosphorus Utilized}

A preliminary experiment was made in which a sample of sea water was enriched with ample phosphate, iron and silica. Portions of this were further enriched with $0.25,0.5, \mathrm{I} \cdot 0$ and $2 \cdot 0 \mathrm{mg}$./1. nitrate $\mathrm{N}$. After 5 days (March 20-25) in a north window, there was a growth of diatoms in all the flasks, the increased growth due to $0.25 \mathrm{mg}$./1.N. being very marked, and the growth due to higher concentrations only somewhat greater. After a further three days there was a regular apparent gradation in growth in the five flasks, the population density appearing to be doubled due to a doubling in quantity of added nitrate nitrogen. The community contained Thalassiosira two spp., Skeletonema 
costatum, Lauderia borealis, Ditylum Brightwelli and Phaeocystis, which together formed the dominant species.

Samples were taken from each flask and the phytoplankton separated by centrifuging. Their yellow-green pigment was dissolved in acetone and the colours compared with standard colours (Harvey, 1934). The linear relation between pigment in the diatoms and nitrate $\mathrm{N}$ added is shown in Fig. I.

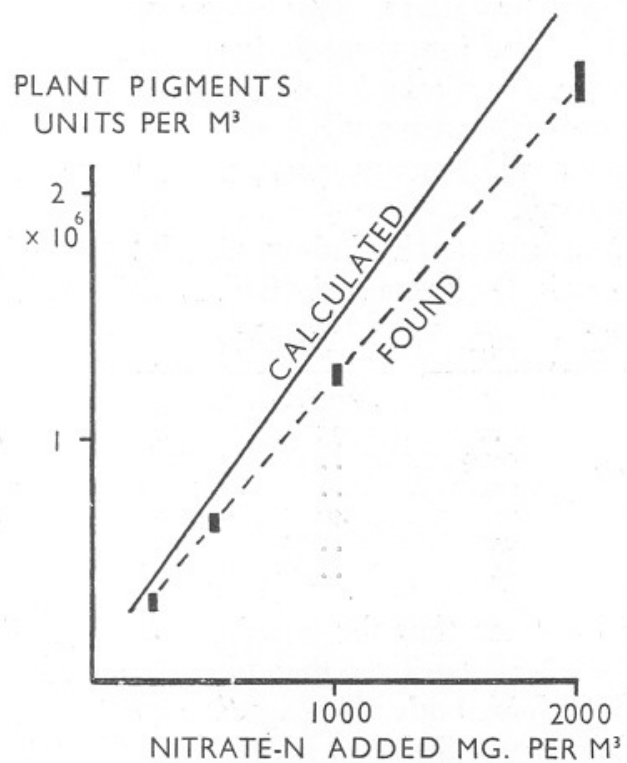

Fig. I. Diagram showing quantities of plant pigment in phytoplankton grown on varying quantities of nitrate.

It had been found during the spring of 1934 that net-caught diatoms contained, on the average, I000 units of plant pigments per $0.08 \mathrm{mg}$. phosphorus (Harvey et al., 1935).

The following analyses of diatoms from the English Channel and American coast suggest an average content of nine times more nitrogen than phosphorus diatoms as they occur naturally in the sea.

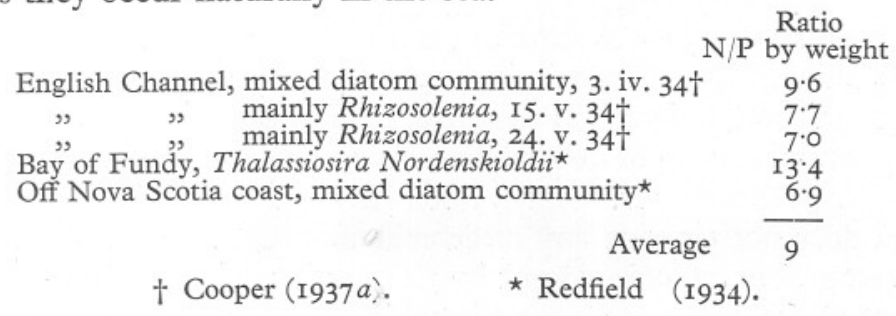

Hence it may be concluded that, as a rough average value, diatoms occurring naturally contained some I 400 units of plant pigment per milligram of nitrogen. 
Applying this value to the present experiment, the calculated line shown in Fig. I was drawn.

The result of the experiment suggests that the method is suitable for biological analysis, provided that growth is slow, at a reasonably cool temperature and that the flasks receive similar illumination.

In the next experiment a sample of sea water was enriched with iron and silica and divided into two parts. One part was enriched with $0.2 \mathrm{mg}$. $/ 1$. phosphate $\mathrm{P}$ and subdivided into three flasks; to one of these no addition was made, to another $0.5 \mathrm{mg} . / 1$. nitrate $\mathrm{N}$, and to the third $\mathrm{I} \cdot 0 \mathrm{mg} . / 1$. nitrate $\mathrm{N}$. The other part was enriched with $2 \mathrm{mg}$. /1. nitrate $\mathrm{N}$ and subdivided into three flasks; to one of these no addition was made, to another $0.05 \mathrm{mg}$. $/ 1$. phosphate $\mathrm{P}$, and to the third $0 \cdot \mathrm{I} \mathrm{mg}$./l.

After varying periods in a north window, samples were taken from the flasks and the plant pigment in the contained diatoms estimated.

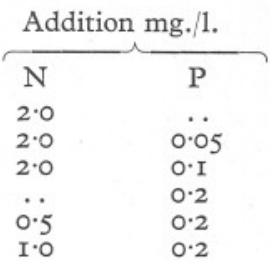

\begin{tabular}{|c|c|c|}
\hline \multicolumn{3}{|c|}{ Plant pigment units per litre } \\
\hline After 4 & 6 & 8 days \\
\hline 75 & 89 & \\
\hline$\cdots$ & 865 & 801 \\
\hline$\ddot{40}$ & $\begin{array}{r}1600 \\
44\end{array}$ & I64I \\
\hline.. & 932 & $\ddot{800}$ \\
\hline. & 1865 & 1600 \\
\hline
\end{tabular}

The experiment indicates that for equal production of diatoms roughly nine times more nitrate $\mathrm{N}$ was utilized than phosphate $\mathrm{P}$. Thalassiosira gravida, Lauderia borealis, Biddulphia regia, Phaeocystis, Chaetoceros two spp., Ditylum Brightwelli and Skeletonema costatum were dominant; Thalassiothrix nitzschioides, Asterionella japonica, Nitzschia sp., Rhizosolenia alata, Bacillaria paradoxa and Streptotheca thamensis were also present.

The experiment was repeated and gave a result which indicated that 10.4 times more nitrate $\mathrm{N}$ was utilized than phosphate $\mathrm{P}$. In this water Thalassiosira gravida, Lauderia borealis and Chaetoceros two spp., formed the bulk of the production.

\section{Direct Utilization and Preference for Ammonium}

It has been shown that ammonium can be utilized as a source of nitrogen by the unicellular algae Carteria (Schreiber, 1927), Chlamydomonas (Braarud \& Föyn, I930) and Chlorella (Pearsall \& Loose, 1937), in cultures free from bacteria. Several species of marine diatoms with their associated bacteria have also been found to utilize it. On the other hand the distribution of ammonium in the sea does not provide any clear evidence that it is utilized as such by phytoplankton, but, as pointed out by Cooper (1937b), this is not remarkable on account of the complex changes in which it is continuously taking part.

Since the productivity of any area of the sea may be limited by the rate at which utilizable nitrogen is set free in the processes of digestion and decay, 
it is a matter of interest whether a phytoplankton community can use the earlier products of nitrogenous breakdown as well as the final product, which is nitrate.

A number of experiments have been made in which quantities of ammonium $\mathrm{N}$ up to $2.0 \mathrm{mg}$. / 1 . have been added in place of nitrate $\mathrm{N}$. The resulting growth was similar in quantity and composition to that brought about by an equal quantity of nitrate $\mathrm{N}$. The same waters enriched with ammonium but kept in the dark during the period of the experiment were found to have undergone no detectable decrease in ammonium or increase in nitrate. There was no material change of ammonium to nitrate or nitrite.

This provides evidence that communities of diatoms such as occur in the spring can utilize ammonium directly.

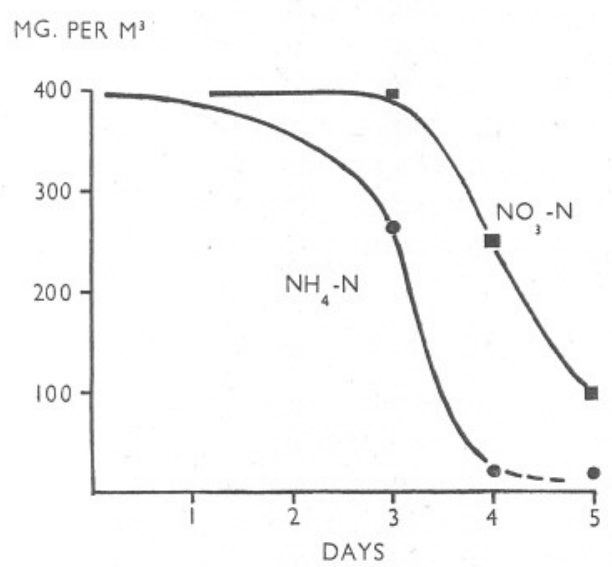

Fig. 2. Diagram showing fall in concentration of nitrate- and ammonium-nitrogen due to the growth of phytoplankton.

In some of the experiments, growth of the diatoms appeared to be slightly more rapid when supplied with ammonium than with an equal quantity of nitrate N. Pearsall \& Loose (1937) had found that Chlorella would use ammonium-nitrogen more rapidly than nitrate $\mathrm{N}$ when grown in a solution containing equal quantities of both.

An experiment was therefore made with crude sea water adding equal quantities ( $(0.4 \mathrm{mg}$. $/ 1$.) of ammonium and nitrate $\mathrm{N}$, mixed together, as a source of nitrogen. Analyses made at intervals during the growth of the resulting diatoms, gave values which are shown in Fig. 2. Most of the ammonium was used before there was any appreciable utilization of nitrate. Thalassiosira gravida and Rhizosolenia delicatula were dominant; Eucampia zoodiacus, Skeletonema costatum, Phaeocystis and Chaetoceros sp. being also present.

It appeared possible from this result that the more rapid utilization of ammonium was not merely due to the more rapid diffusion of its ion than of the nitrate ion. In order to investigate this possibility an experiment was made 
where the added nitrogen consisted of $30 \mathrm{mg}$./1. nitrate $\mathrm{N}$ and $0.5 \mathrm{mg}$./1. ammonium $\mathrm{N}$. When the growth of diatoms had reached a population density which appeared on inspection similar to a growth which had utilized between 0.5 and $\mathrm{I} .0 \mathrm{mg} . / 1 . \mathrm{N}$, analysis showed that the ammonium $\mathrm{N}$ had been reduced, from the $0.5 \mathrm{mg}$./1. added, to $c a .0 .025 \mathrm{mg}$./1., possibly less. A sample of the same enriched water had been kept in the dark and this was found to have suffered no appreciable change in ammonium content. From this result it is concluded that the diatoms utilized nearly all the ammonium before any material quantity of the nitrate was used, although the latter was sixty times more concentrated at the beginning of the experiment, and many times more towards the end. That bacteria had not converted the ammonium to nitrate or nitrite was indicated by the analysis of the same water kept in the dark.

The possibility remained that the algae themselves converted nitrate to ammonium in the external medium. Warburg \& Negelein had found that ammonium was produced in a nitrate solution in which Chlorella were suspended and kept in the dark. Experiments failed to show that marine diatoms did this; very small quantities of ammonium were found in the nitrate-enriched sea water in which the diatoms had been kept in the dark for several days, but not more than might be accounted for by breakdown of the diatoms.

\section{UTILIZATION OF UREA AND URIC ACID}

Experiments showed that nitrate or ammonium, added as a source of nitrogen, could be replaced by both urea and uric acid. With the former, growth was usually slower than with an equal quantity of nitrate $\mathrm{N}$, and the final crop or total production of diatoms was in some cases less. With uric acid growth was slower and the final crop materially less, not more than $50 \%$ in some cases.

It was found that if a subsample of the water with added urea or uric acid was kept in the dark during the course of the growth experiment, there was only an insignificant increase in its ammonium content. It would appear from this that most of the urea and uric acid was utilized directly. The phytoplankton community which developed with nitrogen added as nitrate, ammonium, urea or uric acid was similar in composition, with the exception of one experiment where the two latter sources of nitrogen led to a greater proportion of Skeletonema costatum, the other dominant species present being Thalassiosira two spp., Lauderia borealis and Ditylum Brightwelli.

\section{Amino-ACids as a SOURCE OF Nitrogen}

Although amino-acids have not been identified as occurring in sea water, their presence is probable, derived both from the early stages of the breakdown of organic matter and from the excreta of invertebrates. Baldwin (1937) cites analyses of the excreta of seven species, where amino-acids account for I $4 \%$ 
of the total nitrogen. Moreover, significant quantities of dissolved amino-acids have been determined in lake water, amounting to some $0.08 \mathrm{mg} . / 1 \mathrm{~N}$ (Peterson et al., r925).

Nitrogen in this form can be utilized by bacteria-free cultures of Carteria (Schreiber, I927) and of Chlamydomonas (Braarud \& Föyn, I930); there is no knowledge whether marine diatoms, such as form the bulk of most phytoplankton communities, can utilize them directly, that is without previous breakdown to ammonia.

In an experiment where amino-acetic acid and where $\alpha$-amino-propionic acid were added to crude sea water as a source of nitrogen, the resulting growth of diatoms was indistinguishable from the growth in a flask supplied with an equal quantity of nitrate $\mathrm{N}$. It was found that ammonia was being set free in the water more rapidly than the diatoms were using it. In other experiments with $\alpha$-amino-propionic acid growth was not always so rapid as with nitrate and in some cases the crop was slightly less. Similar results were obtained using $\beta$-amino-propionic acid and using proline as initial sources of nitrogen. With $l$-leucine variable small growths were obtained, the best growth was roughly one-third of that obtained with an equal addition of nitrate nitrogen. In this experiment it is noteworthy that no growth took place due to an equal addition of $d$-leucine nitrogen.

These experiments show that some amino-acids can be used by communities of marine diatoms with their associated bacteria, but provide no evidence whether they can be used directly without deamination in the external medium.

Kreps (I934) has presented evidence that some changes in the nitrogen and phosphorus cycle in sea water may be brought about through the agency of catalysts or enzymes. With the aim of finding whether such caused any material part of the deamination which occurred in these experiments, or whether the ammonium set free was due almost entirely to bacterial breakdown, crude sea water and the same after passing through a Seitz filter were added to $\alpha$-alanine and the solutions kept for 5 days. A very heavy production of ammonium had taken place in the crude sea-water solution, but no detectable production in the solution made with Seitz filtered water.

\section{Trimethylamine Oxide}

This substance has been found in the urine of a marine teleost, forming $23 \%$ of the total nitrogen (Baldwin, I937) and is doubtless a potential source of combined nitrogen in sea water. Several experiments failed to show any increased growth of phytoplankton due to its addition to samples of crude sea water.

\section{Organic Phosphorus Compounds}

The productivity of an area of the sea is limited inter alia by the rate at which phosphorus, in a form which phytoplankton can use, is returned, after the death of organisms, to the upper layers. Sea water contains organic 
phosphorus compounds in solution in addition to phosphate; Redfield et al. (1937) have shown how these dissolved organic compounds accumulate in the water during the summer and are mostly broken down to phosphate during the winter. Their chemical nature is unknown. Surmise suggests that much nucleic acid must pass into the water during the course of a year from the sperm and ova shed by the animal population. Gardiner (1937) has shown the rapid regeneration of phosphate by copepods feeding on phytoplankton, but the proportion which is excreted as phosphate and which may be returned to the water as phospho-proteins and glycerophosphate compounds in partially digested faeces is unknown.

With these considerations in view, the effect of adding sodium nucleinate, caseinate and glycerophosphoric acid to crude sea water, in place of phosphate, has been tried. Sodium nucleinate brought about a similar growth and crop of diatoms to that brought about by an equal addition of phosphate P. A subsample kept in the dark showed on analysis that phosphate had been rapidly formed from the nucleinate. No such dephosphorulation occurred in water which had passed a Seitz filter, so it appears that marine bacteria very rapidly attacked nucleic acid.

The addition of caseinate led to a similar final growth, but growth was slower. The addition of glycerophosphate had no apparent effect.

It is noteworthy that none of these compounds give the Atkins-Denigès phosphate reaction.

Throughout these experiments thorough "bacteriological" precautions against possible contamination of the water samples were not taken, as the chance of such affecting the results seemed negligible.

I am indebted to Miss M. Mare for the identification of many diatom species and to $\mathrm{Mr} \mathrm{R}$. J. Harrison for analyses of the phosphorus compounds used.

\section{SUMMARY}

A method is described for obtaining growths of phytoplankton in samples of crude sea water, similar in composition but several hundred times more dense than phytoplankton communities occurring in the sea.

The ratio of nitrogen to phosphorus utilized by such communities has been determined.

They use ammonium in preference to nitrate, although the latter may be many times more concentrated than the former.

They use urea and uric acid as sources of nitrogen.

Certain amino-acids when added_as sources of nitrogen were attacked by the bacteria in the community and either the ammonium set free or both the ammonium and the amino-acid were used by the phytoplankton. Others, as $d$-leucine, were not utilized, or, as $l$-leucine, only slowly utilized. 
Sodium nucleinate and caseinate were rapidly broken down when added to crude sea water by bacterial action, and the phosphate produced utilized by phytoplankton. There was no significant utilization of glycerophosphate.

\section{REFERENCES}

Allen, E. J. \& Nelson, E. W., I9Io. On the artificial culture of marine plankton organisms. Fourn. Mar. Biol. Assoc., Vol. x, pp. 4I7-39.

Baldwin, E., 1937. An Introduction to Comparative Biochemistry. Cambridge University Press.

BraARUd, T. \& Föyn, B., I930. Beiträge zur Kenntnis des Stoffwechsels im Meer. Avh. Norske Videnskap Akad., No. I4, pp. I-24.

Cooper, L. H. N., I937a. On the ratio of nitrogen to phosphorus in the sea. Fourn. Mar. Biol. Assoc., Vol. xxi, pp. I77-82.

- I937b. The nitrogen cycle in the sea. Fourn. Mar. Biol. Assoc., Vol. xxi, pp. I83-204.

GARDINER, A. C., I937. Phosphate production by planktonic animals. Fourn. Cons. Int. Explor. Mer., Vol. xIr, pp. I44-46.

Harvey, H. W., I934. Measurement of phytoplankton population. Fourn. Mar. Biol. Assoc., Vol. xIX, pp. 76I-73.

Harvey, H. W., Cooper, L. H. N., Lebour, M. V. \& Russell, F. S., I935. Plankton production and its control. Fourn. Mar. Biol. Assoc., Vol. xx, pp. 407-4I.

KREPS, E., I934. Organic catalysts or enzymes in sea water. Fames fohnstone Memorial Volume, Liverpool, pp. 193-202.

Lloyd, B., 1937. Bacteria in stored sea water. Fourn. Roy. Tech. Coll. Glasgow, Vol. IV, p. I73.

Pearsall, W. H. \& Loose, L., I937. The growth of Chlorella vulgaris in pure culture. Proc. Roy. Soc., B, Vol. cxxi, pp. 45I-50I.

Peterson, W., Fred, E. \& Domogalla, B., I925. The occurrence of amino acids and other organic nitrogen compounds in lake water. Fourn. Biol. Chem., Vol. LxIII, pp. $287-95$.

REDFIELD, A. C., I934. On the proportion of organic derivatives in sea water and their relation to the composition of plankton. Fames fohnstone Memorial Volume, Liverpool, pp. I76-92.

Redfield, A., Smith, P. \& Ketchum, B., I937. The cycle of organic phosphorus in the Gulf of Maine. Biol. Bull., Vol. LxxiII, pp. 42 I-33.

SCHREIBER, E., I927. Die Reinkultur von marinen Phytoplankton. Wiss. Meeresuntersuch. Abt. Helgoland., N.F., Bd. I6, No. 10, pp. I-34.

Waksman, S. A., Reuzer, H. W., Carey, C. L., Hotchkiss, M. \& RenN, C. E., I933. Biology and chemistry of the Gulf of Maine. III. Bacteriological investigation of the sea water and marine bottoms. Biol. Bull., Vol. LXIv, pp. 183-205.

WARBURG, O. \& Negelein, F., I920. Ueber die Reduction der Saltpetersäure in grünen Zellen. Biochem. Zeitsch., Vol. cx, pp. 66-Ir5. 